\title{
A STUDY ON FOREIGN LANGUAGE TEACHING MODEL FOR TOURISM UNDERGRADUATE PROGRAMS
}

\author{
TURİZM LİSANS PROGRAMLARI İÇİN YABANCI DİL ÖĞRETİM MODELİ \\ ÜZERİNE BİR ÇALIŞMA
}

\author{
Saadet PInar TEMIZKAN ${ }^{1}$ \\ Rahman TEMIZKAN ${ }^{2}$
}

\begin{abstract}
Referring to the fact that the tourism sector offers a lot of job opportunities tourism undergraduate programs have an important place in the tourism education system in Turkey.Due to the importance of foreign language (FL) skills in the tourism sector, it is necessary to revise foreign language teaching models of these programs. The purpose of the study is to determine the perceptions, expectations and suggestions of students and faculty members regarding the foreign language teaching models applied in undergraduate (4 years) tourism programs. A questionnaire form based on a comprehensive review of the relevant literature was developed, opinions of academic colleagues of the authors and experiences of the authors form the basis for this questionnaire, the research was conducted by personal interviews with the students. Results show that surveyed students have considered "concentrated FL teaching model" as the most effective and desired FL teaching model in bachelor's degree programs in tourism. Students' perceptions about the effectiveness of their programs have been differentiated depending on differences on applied FL teaching model in the programs.
\end{abstract}

Keywords: Foreign Language Teaching, Tourism Education, Tourism, Preparatory Class, Tourism Bachelor's Degree Programs

$\ddot{\mathbf{O z}}$

Sektörde istihdam edilme firsatı sağladıkları için lisans düzeyinde eğitim veren turizm programları Türkiye'nin turizm eğitim sisteminde önemli bir yere sahiptir. Turizm sektöründe sahip olunan yabancı dil bilgisine büyük önem verildiği için bu programların yabancı dil öğretim modellerinin gözden geçirilmesi gerekmektedir. Bu çalışmanın amacı öğrencilerin ve öğretim elemanlarının lisans düzeyinde turizm eğitimi veren programlarda uygulanan yabancı dil öğretim modelleri hakkındaki algılarını, beklentilerini ve önerilerini ortaya çıkarmaktır. İlgili literatürün taranması, yazarların akademisyen meslektaşlarının görüşlerinin alınması ve yazarların deneyimlerine dayanarak bir anket geliştirilmiş ve öğrencilere yüz yüze görüşerek uygulanmıştır. Sonuçlar araştırmaya katılan öğrencilerin "yoğunlaştırılmış yabancı dil öğretim modelini” turizm lisans programlarında en etkili ve arzulanan model olduğunu düşündüklerini göstermektedir. Öğrencilerin, öğrencisi oldukları programların verimliliği hakkındaki algıları bu programlarda uygulanan yabancı dil eğitim sistemine göre değişmektedir.

Anahtar Kelimeler: Yabancı Dil Öğretimi, Turizm Eğitimi, Hazırlık Sınıfı, Turizm Lisans Programları

\footnotetext{
${ }^{1}$ Yrd. Doç. Dr. Eskişehir Osmangazi Üniversitesi, Turizm Fakültesi pinartemizkan@hotmail.com

${ }^{2}$ Yrd. Doç. Dr. Eskişehir Osmangazi Üniversitesi, Turizm Fakültesi rahmantemizkan@hotmail.com
} 


\section{INTRODUCTION}

Due to making economic contributions, such as supporting the balance of payments and providing employment opportunities, tourism has become an extremely important sector for developing countries. Meanwhile, developed countries have been taking the largest share from international tourism income (Dieke, 1988:41; Tosun, 1999:217). Tourism is a laborintensive service industry. Most tourism and hospitality services are provided in interpersonal interactions. Thus, satisfying the client depends on the attitudes, behaviors and skills of service providers and their managers (Little and Dean 2006; Rhodes 2006, Amoah and Baum, 1997, Zagonari, 2009, Christou, 1999)

Especially, front-line employees are "the first and only representation of a service firm" (Hartline, Maxham, and McKee, 2000: 35). As tourism and hospitality businesses are people oriented (Lam, Zhang, and Baum, 2001) and labor intensive (Zagonari, 2009), employees are predominantly the first and only representation of firms. Having a skilled, enthusiastic, and committed workforce is regarded as being vital to the success of firms in the industry (Kusluvan and Kusluvan, 2000). Most of the interactions between customers and clients in the industry take the form of face-to-face exchanges, service is purchased and consumed simultaneously, and so, the standard of provided service is of paramount concern. Attitudes, performance, and behaviors of employees are key determinants of service quality, which has a direct effect on customer satisfaction and loyalty (Heskett, Jones, Loveman, Sasser, and Schlesinger, 1994; Bettencourt and Brown, 1997).

The main priority is to be able to hold a conversation and understand the needs of guests or customers (Leslie, Russell and Govan, 2004). It is obvious that engaging in effective communication with customers plays an important role in customer satisfaction. There is no doubt that foreign language (FL) is the key skill supporting successful communication with international tourists. Indeed, mastering FL skills are essential for people working in the tourism sector, as these skills increase the job opportunities of employees in this international industry (Leslie and Russell, 2006). Therefore, applying an efficient model of FL teaching has got vital importance in tourism education.

Recognizing this importance, this study aims to contribute to efforts to determine the appropriate Foreign Language Teaching Model (FLTM) for undergraduate tourism programs. Despite the importance of FL ability of tourism employee, there is diversity and ambiguity with regard to the FLTM applied in tourism undergraduate programs. Determining of an 
effective model will satisfy the graduates, the employers and the market. The main aim of this research is to determine the most satisfying and effective FLTM for tourism undergraduate programs. Therefore, findings of this study are intended to bring clarity to the satisfaction levels of students and academicians with the FLTM in use. Suggesting an appropriate FLTM for the model is another purpose of this study.

Tourism undergraduate programs which are aiming to provide knowledge, abilities and experiences needed by students to be employed at middle and top management positions (Avcıkurt and Karaman, 2002; Demirkol, 2002; Ünlüönen, 2004; Yeşiltaş et al., 2010; Hacioğlu et al., 2008; Pauze, 1993; Ünlüönen and Boylu, 2005) should choose the most efficient FLTM. Graduates of programs which are applying the most effective FLTM will get vital competitive advantage in the labor market. At this point, some questions are waiting to be answered. What are the satisfaction levels of students from the FL teaching models? What are the alternatives of FLTMs? How much support do the new suggested FLTMs have among students?

It is expected that the findings and the results of this research will enlighten the decision makers on selecting the appropriate FLTM for tourism undergraduate programs. This research is very important, as it will be a foundation for further studies related to FL development.

\section{LITERATURE REVIEW}

Academic tourism programs have primarily emerged in Europe, followed by counterparts in North America, Australia and New Zealand. Early institutions in Europe generally analyzed the tourism sector at the macro level. It can be stated that, institutions have not consider the needs and expectancies of firms in the tourism sector fairly since these primarily ones (Jenkins, 1996). It is clear that there is diversity in opinions and approaches on tourism education systems in the world. This diversity leads to a wide range of lesson curricula available at tourism education institutions. In addition, the curricular variations may be observed among tourism education institutions also within countries (Mayoka and Akama 2007; Amoah and Baum, 1997; Barrows and Bosselman, 1999; Dale and Robinson, 2001; Okumuş and Yağcı, 2006; Zagonari, 2009).

In terms of the sector, employers may not make any judgment regarding graduates because there is no standard with which to determine the quality of the education provided by institutions. There are difficulties in comparing tourism programs between and within countries (Jenkins, 1996). Although all stakeholders may recognize the importance of FL 
ability, tourism undergraduate programs in Turkey, as in other countries, have different language teaching approaches from the aspect of credits and hours of FL lessons per week (Okumuş and Yağc1, 2006, Hussein et al., 2008).

Studies on tourism development in Turkey often cite the lack of qualified manpower and poor service quality as being the tourism industry's main problems (Okumus and Kilic, 2004; Tosun, 2001; Yeşiltaş, Öztürk and Hemmington, 2010). One potential solution to these problems is to use efficient and qualified tourism education systems to equip employees with the necessary knowledge and abilities (Ünlüönen, 2000) and to increase the employment of graduates of tourism schools (Kusluvan and Kusluvan, 2000). However, some industry members claim that graduates from tourism schools are lack of the skills and knowledge needed for service delivery, speaking FLs, and communication skills with customers (Okumuş and Yagci, 2006). Identifying and addressing the causes of these problems are important for all stakeholders.

There are three different types of higher education programs in tourism in Turkey: pre-degree (associate), undergraduate (bachelors), and postgraduate programs (Okumuş and Yagci, 2006). A total of 69 institutions, which are departments or faculties that are part of various universities, provide tourism bachelor's degree programs in Turkey (OSYS 2012). Although there are important similarities in the challenges they face, there are also differences in how the different programs manage these challenges (Okumuş and Yagci, 2006).

Representing one of the most important problems faced when seeking qualified staff in the sector is degree candidates' relative lack of FL skills (Sevgi, 1992). Leslie and Russell (2006) have noted that in the context of a competitive global market, having one or more FLs are increasing in importance for potential employees willing to work in the tourism sector, which entails intensive international relationships. In the Turkish context, this sector has been evolving, especially in international tourism, with employers placing great emphasis not only on tourism education but also on FL ability. Consequently, graduates have employment problem depending on FL issue and this has been explored in many studies (Avc1kurt and Karaman, 2002; Demirkol, 2002; Gürdal, 2002; Çetin, 2002).

In Turkey, FL ability is so important that a person may be employed in a management level position thanks to his/her high level of FL ability even if he/she is not educated in tourism. This condition is one of the strongest barriers preventing bachelor's graduates from becoming employed in management positions within the sector (Demirkol, 2002). FL ability is a 
prerequisite for the sector, especially for the management positions (Gürdal, 2002). Çetin (2002) has stated that the primary characteristic driving employment at a management-level position and having a stable career in the sector is high FL ability. FL ability is also an important factor enabling graduates to find employment in other sectors. As a lingua franca, English is used to communicate with international tourists in Turkey. Therefore, English is taught as a core FL in higher education programs in tourism and hospitality.

Despite the importance of language for students in tourism, many students have graduated from universities with poor FL skills. Tourism undergraduate programs feature four primary FL teaching models (Hussein, Temizkan and Temizkan, 2008):

1. Normal FL Teaching Model (Classical).

2. Compulsory FL Preparation Class (CFLPC),

3. Concentrated FL Teaching Model or hidden preparation class (CFLTM)

4. Voluntary FL Preparation Class

In the voluntary FL preparation class model, volunteer students may attend 1-year preparation courses but cannot pursue their normal curriculum program lessons during that same year. The success of students has no positive or negative effect on the 4-year actual curriculum being taught and students' records in that 4 year after the preparation class. In this study, as it is difficult to select volunteers and measure volunteerism, the voluntary model is eliminated. Consequently, the first three models are studied.

In programs featuring a compulsory FL preparation class, students should prove their proficiency in FL with a FL proficiency exam to obtain an exemption from the 1-year FL preparation class during the first year of schooling. Students who have passed the exam may pursue a 4-year education by eliminating the compulsory FL preparation class. Students who attend the one-year preparation class should be successful. If they cannot be successful, they begin to pursue a normal 4-year curriculum, but during a 4-year period, they should prove their proficiency in FL with a FL proficiency exam.

In normal FL teaching (classical) model students receive up to 4 hours FL courses per week for 4 years long. It can be deducted that the time spent on teaching/learning FL is inefficient whether the content of FL courses is vocational or general.

The concentrated FL teaching (hidden preparation class) model has no 1-year preparation class. Under this model, students receive 15 hours of FL courses per week in the first year, at 
least 10 hours in the second year, 6 hours in the third year, and 4 hours in the fourth year while completing the rest of the 4-year curriculum.

\section{METHODOLOGY}

This study employed a survey questionnaire as the primary data collection instrument in addition to literature review. The questionnaire draft was developed based on a comprehensive review of the relevant literature, opinions of academic colleagues of the authors and experiences of the authors, and it was conducted through personal interviews. The questionnaire contains open-ended, multiple-choice and Likert-type questions and consists of three sections. The first section includes multiple-selection and open-ended questions about the issues which have effects on FLM preferences of students. The first section aims to learn; what makes students feel themselves deficient in the sector, the satisfaction level of students from the FLTM used in their school, the most needed FL in the sector, the second most needed FL in the sector and students willingness to pursue a master's degree.

The second section gathers the agreement degree of students on the efficiency of FL education at their schools for such career paths: having a career at management level within the tourism industry, working as an intermediate staff, having international career in the sector, progressing in academia and building effective communication with foreign visitors. Items in this section were rated on a 5-point Likert scale ranging from "(1) strongly disagree” to "(5) strongly agree".

The third section involves variables regarding the respondent profile. For the purpose of testing the attitudes of the three different groups of students on learning FLs with different FLTM, four different tourism programs were selected from universities in Turkey. All students in their final year of these four programs were the research subjects. The study population was limited with the students in their final year. Because, it was assumed that they were much more experienced in the sector, completed their training terms, and that they were familiar with the expectations of employers in the industry. The first student group (1) was from the Gazi University Commerce and Tourism Education Faculty, which was applying classical FLTM. The second students group (2) was from the Schools of Tourism and Management of Adnan Menderes University and Mustafa Kemal University, which were applying Compulsory FL preparation class model. Group 3 (3) was from the Nevşehir University Commerce and Tourism Education Faculty, which was applying Concentrated FL courses (hidden preparation class) model. These schools and faculties were selected due to the 
differences in the Foreign Language Teaching Models (FLTM) in use. Questionnaires were distributed to senior students of these programs by random sampling. As colleagues, lecturers helped the researchers to distribute and collect the questionnaires in their lessons.

\subsection{Field Study}

One of the greatest difficulties faced in this study has been the long distances between the schools and faculties under study, which are located in different cities. The task of reaching the students and ensuring that they fill out the questionnaires was accomplished by the support of academic colleagues working at these schools. They distributed and collected the questionnaires and sent the completed responses to the authors. As they are academic staff, the authors have got many opportunities to engage in face-to-face interviews with their colleagues on this issue, especially at meetings such as congresses or conferences. The authors also have used online social networks to interview colleagues. Findings from these interactions have become useful on developing questionnaire and interpreting the findings of the questionnaire. A pilot test implemented on Group 1 (Classical FLTM). 20 questionnaires were conducted, and the Cronbach's alpha coefficient calculated for this test was 0.79 for the Likert scale variables. Having found the questionnaire to be reliable, the authors continued the study by using this questionnaire.

\section{FINDINGS}

The profiles of the study respondents are provided in Table 1. Group 1 comprised 67 (56.8\%) males and 51 (43.2\%) females; Group 2 comprised 69 (70.4\%) males and 29 (29.6\%) females; and Group 3 comprised 28 (48.3\%) males and 30 (51.7\%) females. The population of third (3) group which is subjected to "hidden preparation class foreign language teaching model" (FLTM), is noticeably low in comparison to other groups' population because of the fact that researchers couldn't find another school applying the hidden class preparation class FLTM.

The investigated schools essentially have two departments: hospitality management and travel management. Of Group 1, 66 (55.5\%) are in the hospitality management department, whereas $53(44.5 \%)$ are in the travel management department. A majority of Group $2(68 ; 69.4 \%)$ are in the hospitality management department. Group 3 has nearly equal representation of the two departments.

Respondents are split into two categories by their educational history: graduates from vocational high schools (including tourism and hotel keeping vocational high schools) and 
those from regular high schools. Most of the respondents in Group 1 (111;93.3\%) went to vocational high school, whereas most of the respondents of Group $3(50 ; 86.2 \%)$ have a regular high school education. Group 3 has nearly equal representation of the two categories.

In all groups, It is seen that most respondents (Group 1 94.1\%; Group 2 71.4\%; Group 3 72.4\%) experienced one year of CFLPC while they were in high school. Because these students have one year of experience in CFLPC and training in the sector, it should be noted that most respondents in all groups are capable of providing beneficial and accurate evaluations regarding the expectations of employers in this sector and the FL skills needed to meet these expectations.

Table 1. Respondent Profile

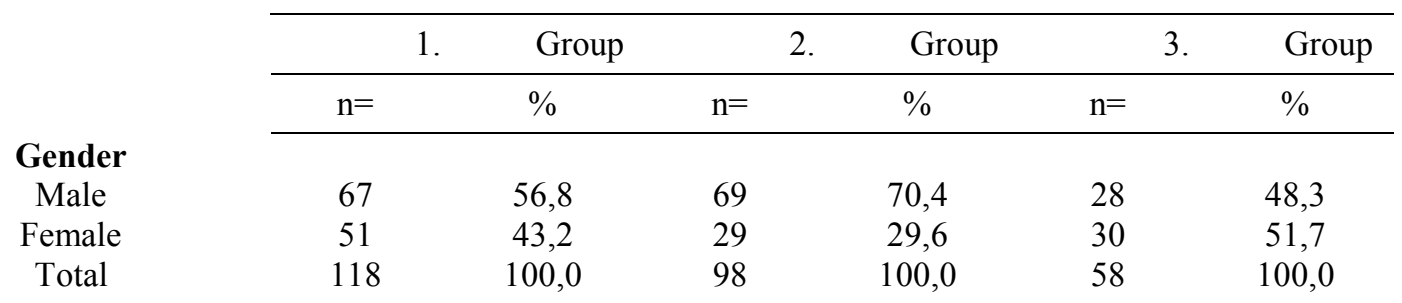

\begin{tabular}{|c|c|c|c|c|c|c|}
\hline Department & & & & & & \\
\hline Hospitality Management & 66 & 55,5 & 68 & 69,4 & 30 & 51,7 \\
\hline Travel Management & 53 & 44,5 & 30 & 30,6 & 28 & 48,3 \\
\hline Total & 119 & 100 & 98 & 100 & 58 & 100,0 \\
\hline \multicolumn{7}{|l|}{ Graduated High School } \\
\hline Vocational High School & 111 & 93,3 & 52 & 53,1 & 8 & 13,8 \\
\hline Regular High School & 8 & 6,7 & 44 & 46,9 & 50 & 86,2 \\
\hline Total & 119 & 100 & 96 & 100 & 58 & 100 \\
\hline \multicolumn{7}{|l|}{ Experience of CFLPC } \\
\hline Yes & 112 & 94,1 & 70 & 71,4 & 42 & 72,4 \\
\hline No & 7 & 5,9 & 28 & 28,6 & 16 & 27,6 \\
\hline Total & 119 & 100 & 98 & 100 & 58 & 100,0 \\
\hline
\end{tabular}

Note: 1. Group (Classical FLTM), 2. Group (Compulsory FL Preparation Class CFLPC) and 3. Group (Concentrated FL Teaching Model, CFLTM)

As it is seen in Table 2, the students provided responses regarding factors potentially affecting their FLM preferences: factors they believe to be most deficient in the sector, students' satisfaction with the FLTM under use at their school, the most needed FL in the sector, the second most needed FL in the sector and desire to pursue a master's degree.

The sample students were asked to choose from given choices one response regarding issues that may affect students' FLM preferences. These students' responses are shown in Table 2. The respondents from Group $1(66 ; 57.9 \%)$ and Group $2(37 ; 37.8 \%)$ rate "foreign language" 
as the factor they believe to be the most deficient in the sector, whereas Group 3 placed "foreign language" in second place $(19 ; 32.8 \%)$ after "professional experience" $(28 ; 48.3 \%)$.

Group 3 reported the highest student satisfaction with $(36 ; 62 \%)$ the FLTM being applied in their school, whereas Group 1 reported the lowest share of satisfied students $(6 ; 5 \%)$.

According to all groups, the most needed FL in the sector is English, and the second most needed FL is German. Group 1 had the highest number and share of students willing to pursue a master's degree $(84 ; 70.6 \%)$.

Table 2. Thoughts on Issues that may affect students' FLM preferences

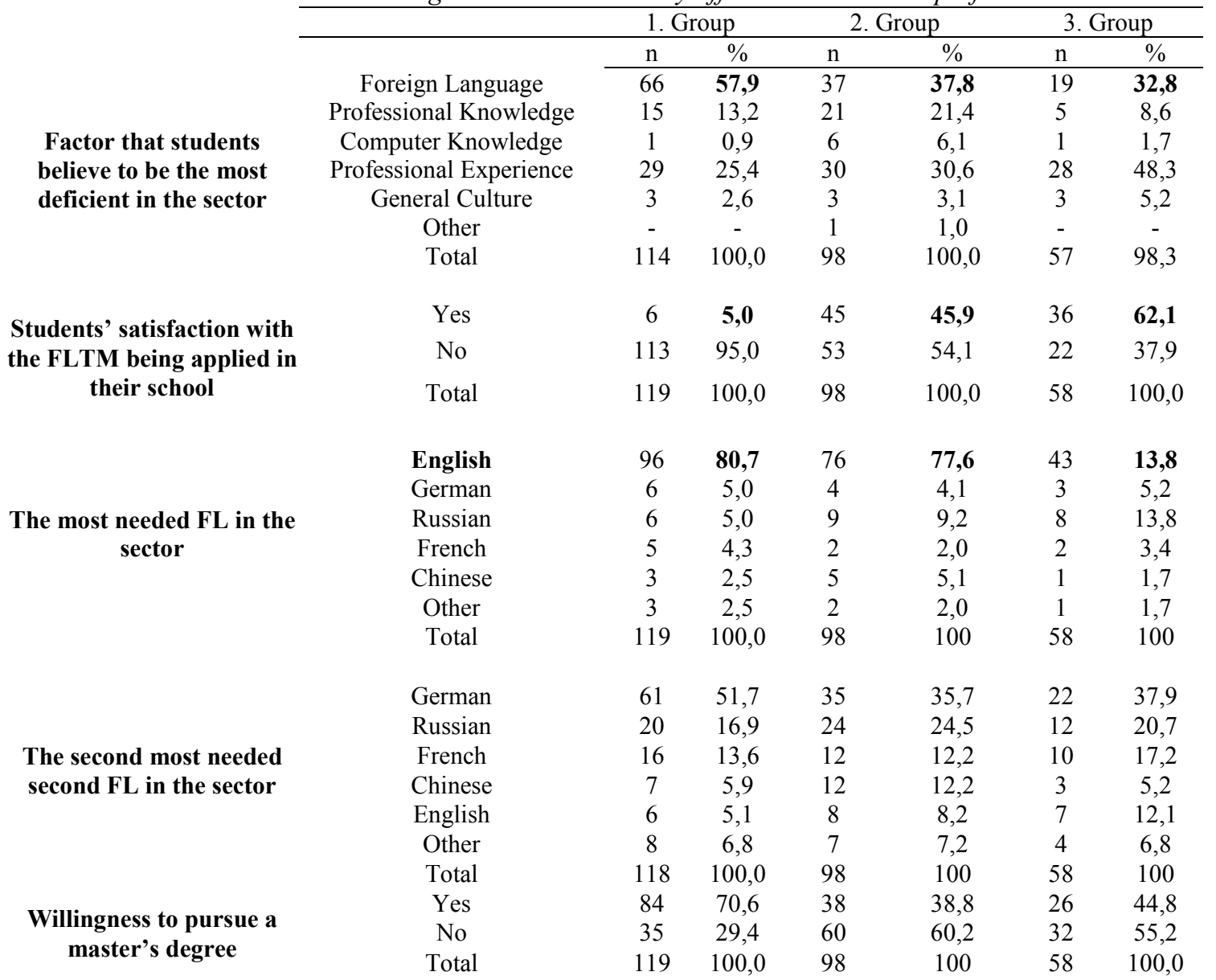

Note: 1. Group (Classical FLTM), 2. Group (Compulsory FL Preparation Class CFLPC) and 3. Group (Concentrated FL Teaching Model, CFLTM)

Table 3 provides mean scores of the three groups' responses regarding the efficiency of FLE at their schools. Students were asked to indicate their agreement with provided statements on a 5-point Likert scale from strongly disagree (1) to strongly agree (5). The seventh variable shown in Table 3, concerns students' agreement with the statement that their school is more effective than the others in FLE. The first variable shown in Table 3 measures students' expected scores on the KPDS (a language exam conducted in Turkey similar to TOEFL and ELS) with the FL education in their school. As shown in Table 3, the averages values for 
Group 3 (students from the school applying concentrated FL teaching or a hidden preparatory class) are higher than the averages for the other two groups.

Table 3. Groups' Beliefs on Efficiency of Foreign Language Education in Their Programs

\begin{tabular}{|c|c|c|c|c|c|}
\hline & & & $n$ & Mean & $\begin{array}{c}\text { Std. } \\
\text { Deviation }\end{array}$ \\
\hline \multirow{5}{*}{1.} & \multirow{4}{*}{$\begin{array}{l}\text { Expected KPDS exam grade may be taken } \\
\text { as a result of FL education in school. }\end{array}$} & 1. Classical FLT & 118 & 1,28 & 0,556 \\
\hline & & 2. Compulsory FLPC & 96 & 1,87 & 0,861 \\
\hline & & 3. Concentrated FLT & 58 & 2,89 & 1,307 \\
\hline & & Total & 272 & 1,83 & 1,060 \\
\hline & \multirow[t]{2}{*}{$\begin{array}{c}\text { Efficiency of foreign language education } \\
\text { in my school on... }\end{array}$} & & & & \\
\hline \multirow{4}{*}{2.} & & 1. Classical FLT & 119 & 1,48 & 0,891 \\
\hline & \multirow{3}{*}{$\begin{array}{l}\text {...prospective career at management level } \\
\text { in the sector }\end{array}$} & 2. Compulsory FLPC & 98 & 2,39 & 1,290 \\
\hline & & 3. Concentrated FLT & 58 & 3,06 & 1,387 \\
\hline & & Total & 275 & 2,14 & 1,312 \\
\hline \multirow{4}{*}{3.} & \multirow{4}{*}{...working as an intermediate staff. } & 1. Classical FLT & 119 & 2,79 & 1,131 \\
\hline & & 2. Compulsory FLPC & 98 & 3,73 & 1,135 \\
\hline & & 3. Concentrated FLT & 58 & $\mathbf{3 , 8 7}$ & 1,215 \\
\hline & & Total & 275 & 3,36 & 1,248 \\
\hline \multirow{4}{*}{4.} & \multirow{4}{*}{...progressing in academic life } & 1. Classical FLT & 119 & 1,63 & ,936 \\
\hline & & 2. Compulsory FLPC & 98 & 2,53 & 1,309 \\
\hline & & 3. Concentrated FLT & 58 & 3,12 & 1,338 \\
\hline & & Total & 275 & 2,26 & 1,307 \\
\hline \multirow{4}{*}{5.} & \multirow{4}{*}{...having international career in the sector } & 1. Classical FLT & 119 & 1,19 & 0,600 \\
\hline & & 2. Compulsory FLPC & 98 & 2,05 & 1,311 \\
\hline & & 3. Concentrated FLT & 58 & 2,55 & 1,244 \\
\hline & & Total & 275 & 1,78 & 1,178 \\
\hline \multirow{4}{*}{6.} & \multirow{4}{*}{$\begin{array}{l}\text {...building an effective communication } \\
\text { with foreign visitors. }\end{array}$} & 1. Classical FLT & 119 & 2,19 & 1,173 \\
\hline & & 2. Compulsory FLPC & 97 & 3,36 & 1,191 \\
\hline & & 3. Concentrated FLT & 57 & 3,77 & 1,085 \\
\hline & & Total & 273 & 2,93 & 1,339 \\
\hline \multirow{4}{*}{7.} & \multirow{4}{*}{$\begin{array}{c}\text { FLE in my school is better than the FLE } \\
\text { in other Tourism Bachelor's degree } \\
\text { Schools }\end{array}$} & 1. Classical FLT & 119 & 2,00 & 1,085 \\
\hline & & 2. Compulsory FLPC & 97 & 3,00 & 1,224 \\
\hline & & 3. Concentrated FLT & 57 & 3,78 & 1,113 \\
\hline & & Total & 273 & 2,73 & 1,335 \\
\hline
\end{tabular}

Table 4 shows the equivalency of IELTS and TOEFL internationally recognized language exams to KPDS. The KPDS exam has a 5-point grading scale from E (the lowest) to A (the highest). Therefore, the evaluation of the variable is adaptable to the Likert scale, which spans from strongly disagree (1) to strongly agree (5). 
Table 4. Equivalency Table of Foreign Language

\begin{tabular}{ccc}
\hline KPDS & TOEFL & IELTS \\
\hline $90-100(\mathrm{~A})$ & $108-120$ & $7-9$ \\
$80-89(\mathrm{~B})$ & $96-107$ & 6,5 \\
$70-79(\mathrm{C})$ & $84-95$ & $5-6$ \\
$60-69(\mathrm{D})$ & $72-83$ & $4-4,5$ \\
$50-59(\mathrm{E})$ & $60-71$ & 3,5
\end{tabular}

Source: OSYM (2013) Equivalency Table of Foreign Language Exams

The average of each response to Likert-scale variables (factors) for each individual participating in the survey was measured. To subject these overall averages to ANOVA test, correlation and regression analysis, which are interval scale measurement, have been conducted as a prerequisite of ANOVA test. Correlation analysis has been revealed moderate or strong uphill (positive) linear relationships $(r>0 ; p<0,01)$ among dependent variable (overall average) and 7 independent variables.

After the conformations of interval scale tests the averages of each response to Likert-scale variables (factors) for each individual participating in the survey were subjected to ANOVA test. The results are shown in Table 5.

Table 5 . Differences in overall averages on issues presented in Table 4 by Groups

\begin{tabular}{lccccc}
\hline & $n$ & Mean & Std. Deviation & Std. Error & f-Value \\
\hline 1, Classical FLT & 119 & 1,76 & 0,653 & 0,059 & \\
2, Compulsory FLPC & 98 & 2,66 & 0,862 & 0,087 & 72,738 \\
3, Concentrated FLT & 58 & $\mathbf{3 , 2 1}$ & 0,936 & 0,122 & \\
\multicolumn{1}{c}{ Total } & 275 & 2,39 & 0,982 & 0,059 & \\
\hline
\end{tabular}

As it is seen in Table 5, ANOVA test clearly revealed meaningful differences $(p=0.00)$ in agreement levels concerning the efficiency of FLE.

\section{DISCUSSION AND CONCLUSION}

It is seen that foreign language ability of the human resources in tourism sector is vitally important. It is important to prefer a FLTM which may produce optimum outputs for all the shareholders like sector, academy, students and their financier families. Tourism sector expects highly satisfying foreign language ability from the graduates. This expectation has also been increasing day by day. English, as the international language of the last periods, may have the priority to be taught as a foreign language. In addition to the strong ability of international language (English) tourism workers are expected to speak at least (2) two other 
foreign language at medium level. After school, climbing the steps of career up faster, the students expect more intensive foreign language education from the schools. This intensive foreign language education can be achieved by additional lessons which may cause additional year to graduation.

Under these circumstances the first (1) model (classical FLTM) with its low number of foreign language lessons hours may not be able to satisfy expectations of students and sector. It may be stated that the first (1) model (classical FLTM) is not efficient and does not produce FL outcomes expected by the sector or academy.

The second model (Compulsory FL teaching class model) delays graduation by one year, extending the 4-year degree program to 5 years. That means, other schools' students - the rivals - will graduate one year earlier and thus will gain an additional year of experience in the sector or in the academy. The model also leads students and their families to bear additional financial costs for, for example, education, nutrition, shelter, and transportation, among others. In addition to these costs, there is also the opportunity cost derived from an additional year out of the labor market. It also doesn't guarantee strong ability of foreign language because after the one year preparatory class, intensive foreign language lessons stop and students almost never have foreign language lessons for the next four year. This may cause concentration lost and erosion of foreign language ability.

The third model (concentrated FLTM) saves students one year, enabling them to save time and money — both the money otherwise spent on an additional year of classes and the income otherwise foregone. In addition to these benefits, however, this model presents some curricular difficulty. An increased number of FL lessons places additional time demands on the curriculum, which also includes professional, science and general culture courses; consequently, credits and lesson except from FL are decreased. Consequently, FL becomes the most important subject, with the other subjects becoming deprioritized.

If the negative dimensions of the different FLTMs are considered, it remains unresolved which FLTM is the most appropriate model for tourism bachelor's degree programs. However, it is clear that graduates with better FL skills have a higher chance of being employed at management-level positions in the sector as well as of being hired for faculty positions.

The survey findings indicate that the FLTM with the most support and producing the greatest satisfaction among students in their final year is third model which is concentrated FLTM. 
Because these students are important stakeholders of tourism degree programs, their perceptions should be considered in addition to faculty members' knowledge and assumptions. Each of the models presents strengths and weaknesses. However, third model (Concentrated or hidden preparation class FL teaching model) is regarded as the most suitable and desirable model for tourism bachelor's degree programs.

Future studies may focus on the perceptions of sector representatives and academics and make comparisons between stakeholders' views regarding FLTM.

\section{REFERENCES}

Amoah, V. \& Baum, T. (1997). Tourism Education: Policy versus practice. International Journal of Contemporary Hospitality Management, 9(1), 5-12.

Avcıkurt, C. \& Karaman, S. (2002). Lisans Eğitimi Veren Turizm Okullarının Ders Programlarının Karşılaştırması (A Comparison of Curriculums of Tourism Bachelor Degree Programs), Turizm Bakanlığı, Turizm Ĕ̆itimi Genel Müdürlügü, Turizm Ĕgitimi Konferansı-Çalıştayı Bildirileri Kitabr (Proceeding Book of Ministry of Tourism, General Directorate of Tourism Education, Workshop-Congress of Tourism Education) 11-13 Aralık (December) 2002, 53-66. Ankara.

Aydos, H. (1992). Türkiye'de Turizm Sektörüne işgücü Yetiştirilmesi Buna yönelik Sorunlar ve Çözüm Önerileri (Problems and Suggestions on Educating Workforce to the Tourism Sector of Turkey), Turizm Ĕgitimi Konferans - Workshop/ 9-11 Aralık, Ankara: Turizm Bakanlı̆̆ Turizm Ĕgitimi Genel Müdürlüğ̈̈ Yayını (Proceedings book of Ministry of Tourism, General Directorate of Tourism Education Congress-Workshop/9-11 December 1992), 175-178. Ankara.

Barrows, C. \& Bosselman, R. (1999). Hospitality Management Education. Binghamton, NY: The Haworth Hospitality Press.

Bettencourt, L. A., \& Brown, S. W. (1997). Contact employees: Relationships among workplace fairness, job satisfaction and prosocial behaviours. Journal of Retailing, 73, 39-61.

Çetin, Ş. (2002). Turizm İşletmeciliği ve Otelcilik Mezunlarının İstihdam Sorunları (Employement Problems of Graduates from Tourism Management and Hospitality Bachelor Degree Programs), Turizm Bakanlı̆̆l, Turizm Eğitimi Genel Müdürlüğü, Turizm Eğitimi KonferanstÇalıştayı Bildirileri Kitabı (Proceeding Book of Ministry of Tourism, General Directorate of Tourism Education, Workshop-Congress of Tourism Education) 11-13 Aralk (December) 2002, Ankara, 485-493.

Christou, E.S. (1999). Hospitality Management Education in Greece an Exploratory Study, Tourism Management, 20: 683-691.

Dale, C. \& Robinson, N., (2001). The theming of tourism education: a three-domain approach. International Journal of Contemporary Hospitality Management 13, 30-35.

Demirkol, Ş. (2002). Turizm Alanındaki Lisansüstü Programların Analizi ve Sektörel Uyumlaştırmaya Yönelik Görüşler (An Analysis of Graduate Degree Tourism Programs and Opinions on Matching with Sector's Expectations), Turizm Bakanlı̆̆l, Turizm Eğitimi Genel Müdürlüğ̈̈, Turizm Eğitimi Konferansı-Çalıştayl Bildirileri Kitabı (Proceeding Book of Ministry of Tourism, General Directorate of Tourism Education, Workshop-Congress of Tourism Education) 11-13 Arallk (December) 2002, Ankara, 87-98

Dieke P.U.C. (1988). The Development of Tourism in Kenya and Gambia: A Comparative Alanysis. Unpublished PhD Thesis, Strathclyde University, The Scottish Hotel School, Glasgow, U.K. 
Gürdal, M. (2002). Türkiye'de Mesleki Turizm Eğitiminin Yapısal Analizi, Okullaşma - Eğitimin Kalitesi - Staj - İstihdam Sorunları ve Çözüm Önerileri, Turizm Bakanlı̆̆ı, Turizm Ĕgitimi Genel Müdürlüğ̈̈, Turizm Eğitimi Konferansı-Çalıştayı Bildirileri Kitabı (Proceeding Book of Ministry of Tourism, General Directorate of Tourism Education, Workshop-Congress of Tourism Education) 11-13 Aralı (December) 2002, Ankara, 391-400.

Hacıoğlu, N., Kaşlı, M., Şahin, S. \& Tetik, N., (2008). Türkiye'de Turizm Eğitimi (Tourism Education in Turkey). Ankara, Detay Yayıncılık.

Hartline, M. D., Maxham, J. G., \& McKee, D. O. (2000). Corridors of influence in the dissemination of customer-oriented strategy to customer contact service employees. Journal of Marketing, $64,35-50$.

Heskett, J. L., Jones, T. O., Loveman, G. W., Sasser Jr., W. E., \& Schlesinger, L. A. (1994, March/April). Putting the service-profit chain to work. Harvard Business Review, 72, 164 174.

Hussein, A., Temizkan, S.P. \& Temizkan, R. (2008). Turizm Alanında Öğretmenlik Eğitimi Veren Lisans Programlarında Yabancı Dil Eğitimi: Akademisyen ve Öğrencilerin Değerlendirmeleri (Foreign Language Education in the Tourism Management Teacher Programs: A Research on Evaluations of Students and Academicians), Ticaret ve Turizm Egitim Fakültesi Dergisi (Journal of Commerce and Tourism Education Faculty), 2008(1), 102-119. http://www.ttefdergi.gazi.edu.tr/makaleler/2008/Sayi1/102-119.pdf

Jenkins, C.I. (1996). Tourism Educational Systems, Institutions and Curricula: Standardisations and Certification. Proceedings of International Conferance Tourism Industry, The Human Capital in the Tourism Industry in the XXI Century Conferance Papers. Madrid.

Kusluvan, S., \& Kusluvan, Z. (2000). Perceptions and attitudes of undergraduate tourism students towards working in the tourism industry in Turkey. Tourism Management, 21, 251-269.

Lam, T., Zhang, H., \& Baum, T. (2001). An investigation of employees' job satisfaction: the case of hotels in Hong Kong. Tourism Management, 22, 157-165.

Leslie, D. \& Russell, H. (2006). The Importance of Foreign Language Skills in the Tourism Sector: A Comparative Study of Student Perceptions in the UK and Continental Europe. Tourism Management, 27 (6), 1397-1407.

Leslie, D., Russell, H. \& Govan, P., 2004. Foreign language skills and the needs of the UK tourism sector. Industry and Higher Education 18, 255-266

Little, M. M. \& Dean, A. (2006) Links Between Service Glimate, Employee Gommitment and Employee's Service Quality Gapability, Managing Service Quality, 16(5): 460-476.

Mayoka, M. \& Akama, J. S. (2007). Systems Approach to Tourism Training and Education: The Kenyan Case Study: Tourism Management, 28, 298-306.

Morgan, D. L. (1997). Focus Groups as Qualitative Research, Thousand Oaks, California USA: Sage Publications.

Okumus, F. \& Kılıç, H. (2004). Turizm İşletmeleri ve Merkezlerinde Rekabet Avantajı Geliştirilmesi ve Korunmas1, Seyahat ve Otel Isletmeciligi Dergisi, 1(1), 10-17.

Okumuş, F. \& Yağc1, Ö., (2006). Tourism Higher Education in Turkey. Journal of Teaching in Travel and Tourism, Volume: 5, (1-27).

OSYM (2013). Equivalency Table of Foreign Language Exams. <http://www.osym.gov.tr/dosya/169730/h/yabanci-dil-esdegerlikleri-250713.pdf> achieved in october 2013. 
OSYS (2012). 2012 Öğrenci Seçme ve Yerleştirme Sistemi (ÖSYS) Yükseköğretim Programları ve Kontenjanları Kilavuzu (2012 Student Selection and Placement System ÖSYS, The Guide Book of Higher Education Programs and Quatas) $<$ http://dokuman.osym.gov.tr/pdfdokuman/2012/OSYS/2012OSYSKONTKILAVUZ.pdf> achived in May 2013.

Pauze, E.E. (1993). Time for a New Mission in Hospitality Education, Hospitality Tourism Educators, Vol. 5, No.3, pp. 61-62.

Rhodes, D. L. (2006). Growth, Gustomer Service and Profitability Southwest Style.,Managing Service Quality, 16(5): 538-547.

Sevgi, A. (1992). Turizm Eğitimi (Tourism Education), Turizm Eğitimi Konferans - Workshop/ 9-11 Aralık, Ankara: Turizm Bakanlığı Turizm Eğitimi Genel Müdürlüğ̈̈ Yayını (Proceedings book of Ministry of Tourism, General Directorate of Tourism Education Congress-Workshop/9-11 December 1992), Ankara, :19-47.

Tosun, C. (1999). An Analysis of Contributions of International Inbound Tourism to the Turkish Economy, Tourism Economics, 5 (3): 217-250.

Tosun, C. (2001). Challenges of Sustainable Tourism Development in The Developing World: The Case of Turkey. Tourism Management, 22(3), 285-299.

Ünlüönen, K. \& Boylu, Y. (2005). Anadolu Otelcilik ve Turizm Meslek Liselerinde Öğrenim Gören Öğrencilerin Beklenti ve Algılamalarındaki Değişimin Karşılaştırılması (2000-2001 ve 20032004 Ögretim Y1lları) (A Comparison of Changes in Expectations and Perceptions of Anatolian Hotel Keeping and Vocational High Schools' Students (2000-2001 ve 2003-2004 Education Years). Milli Eğitim Ü̧̧ Aylık Eğitim ve Sosyal Bilimler Dergisi (Journal of National Education and Social Sciences). Year:33, Number: 166, 159.

Ünlüönen, K. (2000). 'Turizm İşletmeciliği Öğretmenlik Programlarının Öğrenci Beklentileri Ve Algılamaları Açısından Değerlendirilmesi (Evaluation of Tourism Management Teacher Eduction Bachelor Degree Programs from the Aspect of Students' Expectations and Perceptions), Gazi Üniversitesi Ticaret ve Turizm Ĕ̈itim Fakültesi Dergisi (Journal of Commerce and Tourism Education Faculty), (3) 218-238.

Ünlüönen, K. (2004). Turizm İşletmeciliği Öğretmenlik Programlarının Öğrenci Beklentileri ve Algılamaları Açısından Karşılaştırılması (1998-1999 ve 2003-2004 Öğretim Yılları) (A Comparison of Changes in Expectations and Perceptions of Anatolian Hotel Keeping and Vocational High Schools' Students (2000-2001 ve 2003-2004 Education Years)., Gazi Üniversitesi Ticaret ve Turizm Eğitim Fakültesi Dergisi (Journal of Commerce and Tourism Education Faculty), Say1:1

Yeşiltaş, M., Öztürk, Y. \& Hemmington N., (2010). Tourism Education in Turkey and Implications for Human Resources. Anatolia: An International Journal of Tourism and Hospitality Research Volume 21, Number 1, pp. 55-71

Zagonari, F. (2009). Balancing tourism education and training: International Journal of Hospitality Management, 28, 2-9. 